\title{
Žmonių genealogijos ypatumai
}

\author{
Danielius Serapinas ${ }^{1,2}$, Diana Bekasèné $\dot{e}^{2}$ \\ ${ }^{1}$ LSMU MA Genetikos ir molekulinès medicinos klinika \\ ${ }^{2}$ Mykolo Romerio universitetas
}

Reikšminiai žodžiai: genealogija, protèviai, giminystė, istorija.

Santrauka. Analizuojant žmogaus genomą, DNR struktūras, svarbu pažvelgti ir į žmonijos praeiti, ì žmogaus atsiradimo istoriją. Nuo senų laikų žmones intriguoja jų pačių kilmè. Todèl greta istorijos mokslo gyvuoja ir genealogija - žmogaus ar jo giminės šaknų ieškojimas. Genealogija plačiąja prasme - tai istorijos mokslo šaka. leškoti savo giminės šaknų žmones skatina pačios ¿vairiausios priežastys - tikimybė, jog bus rasta sąsajų su kilmingaisiais, giminystės su talentingais asmenimis ar tiesiog noras sužinoti prosenelių gyvavimo istoriją.

Genea iš graikų kalbos išvertus reiškia gimine, logos - mokslas. Profesionalius genealoginius medžius pradèta sudarinèti tik XVIII a. pabaigoje ir IX a. pradžioje. Tai buvo susiję su turto paveldejjimu, todèl genealoginius medžius galèjo leisti sau sudarinèti tik aristokratai. Markas Tvenas yra pasakęs „Kam mokèti pinigus, norint atsekti savo šeimos medį? Eikit $i$ politika, ir jūsu oponentai tai padarys už jus."

2007 m. Lietuvoje ikurta Lietuvos genealogijos ir heraldikos draugija (LGHD), kuri tyrinëja, sudarinejja genealoginius medžius, konsultuoja asmenis, išduoda kilmès liudijimus, kaupia genealoginių duomenų bazę, kuria virtualųji archyvą. $2013 \mathrm{~m}$. birželio 26 d. sudarytas Lietuvos genealogijos ir heraldikos draugijos dokumentu patikros (LGHD DP) komisijos darbo reglamentas, kuriame nurodoma, kad „Kiekvieno žmogaus, šeimos, giminès istorija sudaro bendrą pynę - mūsų tautos praeitį “ [1], todèl svarbu domètis protèvių šaknimis, savo šalies bei tautos istorija. LGHD DP komisija nagrinejja šeimų genealogines schemas, genealoginius medžius, juos tvirtina, registruoja piliečių prašymus, nagrinëja ir vertina kilmès liudijimams gauti pateiktus dokumentus. LGHD archyvai yra didelè pagalba žmonèms, norintiems sužinoti ir surinkti informaciją apie savo giminès istoriją.

Lietuvos valstybès istorijos archyvas (toliau - LVIA) yra didžiausia Lietuvos istorijos archyvinių dokumentuc saugykla nuo XIII a. [2]. Archyvo dokumentai yra svarbūs ir naudojami tenkinant Lietuvos ir daugelio užsienio valstybių institucijų bei piliečių poreikius. Itin išaugo socialinio teisinio, genealoginio pobūdžio paklausimų skaičius. $2001 \mathrm{~m}$. sausio $1 \mathrm{~d}$. prie Lietuvos valstybės istorijos archyvo buvo prijungtas Lietuvos centrinis metrikų archyvas.

Pastaruoju metu domejjimasis savo šaknimis Lietuvoje vis populiarejja. Anksčiau buvo itin svarbu ieškoti tik savo bajoriškos kilmès šaknų ir ịrodymų, o dabar domimasi apskritai visa savo šeimos, giminès istorija ir praeitimi, nepaisant buvusios kilmès. Sovietmečiu buvo îprasta žiūrèti tik i ateitį, žinios apie praeitị buvo nepasiekiamos dèl genealoginių šaltinių neprieinamumo. Atkūrus Lietuvos nepriklausomybę, situacija pasikeitè. Didikų, bajorijos istorija ir genealogija tapo svarbi istorikams ir piliečiams bajoruc palikuonims. Genealoginiai tyrimai tapo populiarūs ir tarsi savaime būtinu dalyku. Šie tyrimai parodè didikus ir bajorus įvairiapusiškiau - kaip politikus, karius, mecenatus, mokslininkus, kultūros puoselètojus ir kt. Lietuvos Didžiosios Kunigaikštystès (toliau - LDK) didikų, bajorų giminių ar jų šakų genealogijų chronologija apima nuo 1666 m. iki XX a. pradžios. Archyvuose yra pateiktos tiek didikų (pvz., Radvilų, Oginskių, Sapiegų, Tyzenhauzų), tiek lietuvių bajorų (pvz., Bytautų, Stulpinų, Paškevičių, Stankevičių ir kt.) genealogijos, taip pat rusènų (pvz., Valavičių, Sapiegų, Oginskių), vokiečių (pvz., Broel-Pliaterių, Tyzenhauzų), lenkų (Nagurskių ir kt.) bei totorių (Sobolevskių) kilmès giminių. Dauguma genealoginių medžių buvo sudaryta norint įrodyti didikams ir bajorams savo bajorišką kilmę (XVIII a. pab. - XX a. pr.). Tačiau i sudarytus genealoginius medžius būtina žiūrèti kritiškai, kadangi ne visi yra tikslūs - trūksta žinomų kai kurių giminès atstovu arba net kelių kartų. Sudaromų medžių tikslumą ir jų dydị lèmè kiekvienos giminès sukauptų ir išsaugotuc senų dokumentų apie giminę kiekis bei finansinès asmenų galimybès.

Šiuolaikinei kartai darosi svarbu identifikuoti save ne tik dabar, bet ir praeityje. Užsieniečiai savo praeitimi, genealogija domisi gerokai dažniau ir labiau nei lietuviai. Jiems tai labai svarbu, kadangi emigravimas ì svečią šalį atskiria ir nutolina žmogų nuo jo tikrųjų giminès šaknų. Dèl šių priežasčių itin išpopuliarèjo genealoginis turizmas, kuris supažindina asmenị su tam tikrais objektais, tiesiogiai susijusiais su konkrečia šeima, gimine. Tai nèra masinis turizmas, nes per vietoves keliaujama pagal konkrečiai šeimai sudarytą genealogini maršrutą. Šeimai, kuri seka savo giminès istorinėmis pẻdomis, gali būti ìdomi vieta, kurioje gyveno, dirbo, mokèsi ju proseneliai, kokiuc profesijuc atstovai jie buvo, vietovès, kuriose jie palaidoti. Genealoginis turizmas - tai 
alternatyvi ir nauja turizmo atšaka, kurios esmè - praeities ir dabarties sujungimas, prisilietimas prie savųju šaknų. Tai kelioné po vietoves, kuriose kadaise gyveno jūsu protèviai.

Galima sakyti, kad būtent Amerikoje gyvenantys emigrantai ir ju palikuonys išpopuliarino genealogini turizmą, kadangi JAV yra emigrantu šalis, žmonès nori žinoti ir grižžti ten, iš kur yra kilę. Airijoje, Škotijoje genealoginis turizmas išplètotas geriausiai, kadangi iš šių šalių ì JAV emigravo labai daug žmonių, ten jie sukūrẻ itin stiprias organizacijas, kurios skatina palaikyti ryši su tèvyne. JAV Pensilvanijos valstijoje susikūrè internetinè Lietuvos globalinè genealoginè visuomenè [3] (angl. Lithuanian Global Genealogical Society) (toliau - LGGS), kurioje grupé žmoniu dalijosi informacija apie savo lietuviškas šaknis, Lietuvos šeimų istoriją ir padèdavo atlikti genealoginius tyrimus.

\section{GIMINYSTĖS TIPAI}

Šeimos antropologai, nagrinėdami santuokos tikslingumą, giminystès tipus ir jų kaitą, nustatè, kad dažniausiai santuoka priklauso nuo turtinių, valdžios santykių, „kraujo“ grynumo, identiteto ir kilmès [4]. Kilmè yra tikejjimas tam tikrais giminystès ryšiais, kurie perduoda tam tikrus charakterio, socialinio elgesio, protingumo, kultūringumo bruožus. Remiantis antropologija, išskiriami tokie giminystès tipai, kaip kraujo giminyste (ar tiesiog giminystè), vedybu giminyste ir pagal senąją visuomenę - totemine giminystè. Kraujo giminysté - tai dviejuc asmenu santykis, paremtas genetine giminyste pagal bendrą kilmę, kilimą vienas iš kito arba giminyste per socialinị i̊sipareigojimą ìvaikinant [5]. Kraujo giminystę galima suskirstyti ị: - genetinę giminystę pagal bendrą protèvi (pvz., pusbrolis su pussesere, dèdè ir sūnènas, ir kt.);

- genetinę giminystę pagal kilimą vienas iš kito (pvz., motina ir dukté; senelis ir anūkas; ir kt.);

- arba socialinè giminystè, atkurianti tèvų ir vaikų ryšius per socialini ìsipareigojimą ịvaikinant.

Kraujo giminystè net ir kilusi per ivvaikinimą sukelia teisines pasekmes įstatymų numatytais atvejais, t. y. sukelia pareigą išlaikyti savo vaikus ir teisę turto paveldejimą.
Vedybu giminystė apima giminystę pagal savo paties arba artimo kraujo giminaičio santuoką. Toteminiais giminaičiais laikyti visi žmonès, priklausantys tam pačiam totemui.

LR CK išskiria dvi giminystès linijas: tiesioji ir šoninè. Tiesioji giminystès linija - giminystès ryšių sistema tarp protèvio ir jo palikuoniu - tai proseneliai, seneliai, tèvai, vaikai, vaikaičiai, provaikaičiai ir t. t. Šoninè giminystès linija - giminystès ryšių sistema tarp giminaičių, kilusių iš bendro protevio. Tokią sistemą sudaro broliai ir seserys, pusbroliai ir pusseserès, dèdès arba tetos ir sūnėnai arba dukteréčios ir t. t. Artimaisiais giminaičiais laikomi tiesiosios linijos giminaičiai iki antrojo laipsnio imtinai (tèvai ir vaikai, seneliai ir vaikaičiai), arba šoninès linijos antrojo laipsnio giminaičiai (broliai ir seserys). Giminaičiai galètú būti skiriami ì 3 kartas [6]:

1) pirmoji karta: tėvai, broliai ir seserys, palikuonys;

2) antroji karta: seneliai, anūkai, dèdès, tetos, dukterèčios, sūnènai;

3) trečioji karta: pusbroliai ir t. t.

Šie santykių lygiai gali būti matematiškai apibrèžti. Santykių koeficientas gali būti naudojamas apibūdinti dviejų asmenų santykinị genų skaičių, pagrịstą protèvių kilme. Amerikos medicinos asociacija (toliau - AMA) rekomenduoja kiekvienam pacientui turèti šeimos medicininę istoriją. Rekomenduojama, kad informacija, reikalinga surinkti duomenims apie šeimos istoriją, medicinos praktikoje būtų nuolat atnaujinama.

Ši informacija turi būti surinkta, norint sužinoti visą šeimos medicininę istoriją, trijų kartu genealogiją. Realioje medicinos praktikoje ne visada yra surenkama ir naudojama šeimos istorija, todèl AMA siūlo naudoti šeimos istorijos klausimyną, kurị žmonès užpildytų būdami laukiamajame. Tam tikros šeimos situacijos gali sukelti klaidingas išvadas apie šeimos genealogiją. Pavyzdžiui, manoma, kad dalis žmonių turi neteisingai priskirtą tèvystę (angl. mis-assigned paternity). Tai yra labai svarbu DNR tyrimuose. Tokio pobūdžio testuose netyčia gali būti atskleista neteisingai priskirta tèvystè, todèl šiuo klausimu turètų būti diskutuojama informuoto sutikimo metu prieš gaunant reikiamus méginius. Dažnai asmenys nežino savo bendro protèvio ir šiuos giminystès ryšius jie gali iden- tifikuoti būtent surenkant informaciją apie šeimos istoriją. Svarbus dèmesys turètú būti skiriamas tokiems giminystès ryšiams, kaip ịvaikinimas, įseserių ir ibroliu santykiai. Surinkta informacija turi tiksliai atspindèti biologinius ir genetinius giminystės ryšius šeimoje.

\section{GIMINIŲ SANTUOKOS}

Šiandien pasaulyje paplitusios įvairios šeimos formos, todèl XX a. itteisinus žmogaus teisių apsaugą tarptautiniuose teisès norminiuose aktuose (konvencijose, deklaracijose, konstitucijose), pasikeitè daugelis normų, reguliavusių žmogaus socialinị gyvenimą. Daug dèmesio šiuose aktuose skiriama šeimos bei santuokos reguliavimo klausimams. Tokios santuokos sudarymo sąlygos, kaip amžius, veiksnumas, draudimas tuoktis artimiems giminaičiams, monogaminès santuokos, pripažintinos klasikinèmis.

Populiacijoje pratęsiant giminę didelị vaidmenị vaidina santuokos, kurios gali būti atsitiktinès ir neatsitiktinès. Atsitiktinè santuoka - tokia santuoka, kuri sudaroma neatsižvelgiant ì santuokos partnerio genotipą, apie ji sprendžiama iš fenotipo, t. y. partneris pasirenkamas atsitiktinai. Iš tiesų atsitiktinès santuokos yra retos, todèl, kad dažniausiai sutuoktinis pasirenkamas pagal ūgị, išvaizdą, intelekto lygi, odos spalvą ir t. t. Tokios santuokos vadinamos neatsitiktinèmis, arba asortatyviomis. Asortatyvumas yra teigiamas, jei santuoka yra labiau pageidaujama su tokị pati požymị turinčiu asmeniu. Ligų atžvilgiu taip pat yra pastebimi tam tikri asortatyvumo požymiai, pvz., kurčnebylis savo partneriu dažniausiai pasirenka kurčnebylį.

Prie neatsitiktinių santuokų dažnai priskiriamos ir giminiu santuokos. Pasaulyje gausu populiacijų, kuriose giminių santuokos yra itin dažnos, pvz., Anglijoje. Anglijoje nuo senų laikų žmonès mažai keliavo ne tik po pasaulị, bet ir po savo šalies tolimesnes teritorijas, todèl nuo senų laikų tuokdavosi vieni su kitais ne tik pusbroliai ar pusseserès, bet ir broliai su seserimis, ir šiose santuokose gimę vaikai dažniausiai turi igimtų defektų [7].

Giminių santuokos ar santuokos tarp artimų šeimos narių yra svarbi problema genetiniame konsultavime. Genetinio konsultavimo metu yra sprendžiamos žmogaus problemos, 
1 lentelè. Giminingu santykių tipai bei bendru genų proporcija

Dalis genų

pasidalinimo

\section{Pirma karta:}

- Broliai, seserys

- Dizigotiniai dvyniai

- Tèvai

- Vaikai

\section{Antra karta:}

- Pusiau broliai-seserys

- Dèdès, tetos

1/2 (pusè

genų bendri)

- Sūnėnai, dukterèčios

- Antros kartos pusbroliai, pusseserès

Trečia karta:

- Pirmos kartos pusbroliai, pusseserès

- Pusiau dèdès-tetos (dèdès pusbrolis yra pusdè- $1 / 8$ dè)

- Pusiau sūnènai-dukterèčios

2 lentelè. Juridinis santuokos apribojimas esant tam tikro laipsnio giminystei Jungtineje Karalysteje ir JAV

\begin{tabular}{|c|c|c|}
\hline Santuoka & $\mathrm{JK}$ & JAV \\
\hline Tikrųjų brolių-seserų & Neteisèta & $\begin{array}{l}\text { Neteisèta (visose } \\
\text { valstijose) }\end{array}$ \\
\hline Tẻvų-vaikų & Neteisèta & Neteisèta \\
\hline Senelių-anūkų & Neteisèta & Neteisèta \\
\hline Pusiau brolių-seserų & Neteisèta & $\begin{array}{l}\text { Neteisèta } \\
\text { (42 valstijose) }\end{array}$ \\
\hline $\begin{array}{l}\text { Dèdès (tetos)-dukteréčios } \\
\text { (sūnèno) }\end{array}$ & Neteisèta & Neteisèta \\
\hline $\begin{array}{l}\text { Pusiau dèdès-dukterèčios } \\
\text { (pusiau tetos-sūnėno) }\end{array}$ & Neteisèta & $\begin{array}{l}\text { Neteisèta } \\
(18 \text { valstijų) }\end{array}$ \\
\hline $\begin{array}{l}\text { Pirmos kartos pusbrolių- } \\
\text { pusseserių }\end{array}$ & Teisèta & $\begin{array}{l}\text { Neteisèta } \\
(30 \text { valstijų })\end{array}$ \\
\hline $\begin{array}{l}\text { Antros kartos pusbrolių- } \\
\text { pusseserių }\end{array}$ & Teisèta & $\begin{array}{l}\text { Neteisèta } \\
\text { (N. Karolinos valst.) }\end{array}$ \\
\hline
\end{tabular}

susijusios su genetine liga šeimoje ir jos pasikartojimo rizika. Santuokos tarp artimų biologinių giminaičių Vakarų visuomeneje yra nemégstamos ir ì jas žiūrima ịtariai, tai atsispindi istorinèse ir religinėse nuostatose. Kai šeimoje yra sergama paveldima liga, giminių santuokos gali turèti stiprią ịtaką rizikai ligą perduoti savo palikuonims.

Yra trys giminingų santuokų aspektai, ị kuriuos būtina atsižvelgti norint atlikti genetinị konsultavimą. Pirmiausia svarbu tiksliai išsiaiškinti, kaip artimai vienas su kitu yra susiję du asmenys. Antra, kaip genetinès ligos rizika šeimoje gali veikti giminystės paplitimą. Ir galiausiai, kokia yra galimybè, kad šeimos abiejų narių žalingi genai gali būti perduoti vaikui, t. y. kad vaikas yra homozigotinis, paveldejjęs būtent iš šių genų. Pagrindinès giminių kategorijos ir bendrų genų dalis pateikiama 1 lentelèje.

Santuoka tarp pirmos kartos giminaičiu yra griežtai draudžiama teisès ir socialinių papročių. Kraujomaiša tarp tèvo ir dukters, brolių ir seserų sukelia ypač didelių problemų. Santuoka tarp antros kartos giminaičių daugelyje šalių yra taip pat griežtai draudžiama, nors dẻdžių ir dukteréčių santuokos yra leidžiamos kai kuriose Azijos bendruomenèse [7]. Jungtinejje Karalystëje ir JAV yra skirtingai vertinama pirmos ir antros kartų pusbrolių santuokos (2 lentelè).
Giminių santuokos griežtai draudžiamos tarp brolių ir seseru JAV visose valstijose, kitų kartų santuokos yra draudžiamos tik kai kuriose valstijose. Situacija Amerikoje pateikia keletą neatitikimų, nors keletas jų iš dalies buvo pakeisti, pvz., pirmos eilès pusbroliu ir pusseserių santuokos yra neteisètos daugiau nei pusèje valstijų, o pusiau sūnẻnų ir pusiau dukteréčių santuokos yra draudžiamos tik ketvirtadalyje valstijų. 11 valstijų galimos santuokos tarp pusiau brolių ir seserų. Šie faktai rodo, kad yra daug teisinių ir genetinių sunkumų, kas apima giminingų santuoku genetini konsultavimą.

Kai giminių santuokose pasireiškia specifinès genetinès ligos ir dèl to gali kilti rimtų pasekmių norint pratęsti šeimą, asmenys turètų pasverti socialinę naudą prieš genetinę riziką [7]. Visgi pasaulyje gausu uždarų populiacijų, kuriose giminių santuokos yra gana dažnos - t. y. Indijoje, Vidurio Rytų, Arabų šalyse ir kitose izoliuotose populiacijose. Šiuolaikiniame pasaulyje giminių santuokų vis tik mažèja, santuokos tampa vis labiau atsitiktinès.

\section{APIBENDRINIMAS}

Apibendrinant galima teigti, kad genealogija yra pagalbinè istorijos disciplina, tirianti giminių, šeimų ir atskirų asmenų istoriją bei nustatanti giminystès ryšius. Žmogaus genealogija, senųjų archyvų informacija suteikia žmonėms galimybę geriau pažinti savo giminès istoriją, šaknis bei sudaryti giminès - šeimos biologinius medžius.

\section{PECULIARITIES OF HUMAN GENEALOGY}

\section{DANIELIUS SERAPINAS 1,2 , DIANA BEKASENE' ${ }^{2}$}

'DEPARTMENT OF GENETICS AND MOLECULAR MEDICINE LITHUANIAN UNIVERSITY OF HEALTH SCIENCES ${ }^{2}$ MYKOLAS ROMERIS UNIVERSITY

Keywords: genealogy, ancestry,consanguinity, history.

Summary. Analyzing genome it is essential to describe the history of human developmen. From antient times people are interested in their heritage. So paralelly to history sciences, genealogy, that analyzes human roots, is in high importance. Genealogy in some way is branch of history sciences. The reasons for people to look for their roots are very diffrerent: to find some relations with highborns, talented personalities or just to know better history of ancestry.

\section{LITERATŨRA}

1. Lietuvos genealogijos ir heraldikos draugijos Dokumentu Patikros (LGHD DP) komisijos darbo reglamentas, žiūrèti http://www.genealogija.org/index.php/apie-mus/teisiniai-dokumentai/13-dokumentu-patikros-komisijosreglamentas

2. Lietuvos valstybès istorijos archyvas, žiūrèti http://www.archyvai.lt/lt/ Ivia_apie-mus/lvia_istorija.html

3. Lithuanian Global Genealogical Society, žiūrèti http://www.lithuaniangenealogy.org/about_us/index.html

4. Thomas Schweizer, Douglas R. White. Kinship, Networks and Exchange,Cambridge University Press, 1998.

5. Lietuvos Respublikos Civilinis Kodeksas, (3.130 str.).

6. Peter S. Harper. Practical Genetic Counselling 7th Edition, Hodder Arnold, 2010.arper

7. Modell B., Darr A. Genetic Councelling and customary consanguineous marriage, Nat Rev Genet. 2002; 3: 225-230. 